\title{
LIFE QUALITY AMONG ELDERLY WITH OBESITY IN OUTPATIENT CLINIC, DR. SOETOMO HOSPITAL, SURABAYA
}

\author{
Patricia Maria Kurniawati, Hening Laswati \\ Department of Physical and Rehabilitative Medicine, Faculty of Medicine, Airlangga University, \\ Dr. Soetomo Hospital, Surabaya
}

\begin{abstract}
ABSTRAK
Obesitas merupakan salah satu penyakit kronis yang memberikan dampak yang cukup berarti dan dapat mempengaruhi kualitas hidup, terutama pada lansia yang sudah memiliki masalah multidimensional. Penelitian ini bertujuan untuk memberi informasi mengenai pengaruh obesitas pada manula terhadap setiap komponen kualitas hidupnya dengan menggunakan alat ukur kualitas hidup SF-36. Penelitian ini dilakukan pada 105 pasien di ruang rawat jalan Rehabilitasi Medik, Geriatri dam Diabetes di Rumah Sakit Dr. Soetomo. Pasien berusia 60-75 tahun, terdiri dari 62 orang pria dan 43 orang wanita. Jumlah penderita dengan obesitas adalah 49 orang (46,7\%) dengan rata-rata indeks massa tubuh (IMT) sebesar 27,16 kg/m2. Sedangkan pasien yang non-obesitas sebanyak 56 orang $(53,3 \%)$ dengan IMT rata-rata $21,23 \mathrm{~kg} / \mathrm{m} 2$. Hasil analisis menggunakan t-test menghasilkan nilai kualitas hidup SF-36 pada kelompok obesitas dengan non-obesitas yang tidak mempunyai nilai yang berbeda secara signifikan. (FMI 2017;53:185-190)
\end{abstract}

Kata kunci: Obesitas; lansia; kualitas hidup, SF-36

\begin{abstract}
Obesity is one of the chronic diseases that may have significant impact and affect the quality of life, especially in elderly who already have multidimensional problems. This study aimed to provide information about the influence of obesity in elderly on every component of his quality of life by using the SF-36 quality of life. This study was conducted on 105 patients in outpatient Medical Rehabilitation, Geriatrics and Diabetes at Dr. Soetomo Hospital, Surabaya. Patients aged 60-75 years, consisting of 62 men and 43 women. The number of patients with obesity was 49 persons (46.7\%) with an average body mass index (BMI) of $27.16 \mathrm{~kg} / \mathrm{m} 2$. Whereas, non-obese patients were 56 persons (53.3\%) with an average BMI of $21.23 \mathrm{~kg} / \mathrm{m} 2$. In conclusion, there was no significant difference in the SF-36 life quality of obesity and non-obesity groups after being analyzed using t-test. (FMI 2017;53:185-190)
\end{abstract}

Keywords: Obesity; elderly; life quality; SF-36

Correspondence: Patricia Maria Kurniawati, Department of Physical and Rehabilitative Medicine, Faculty of Medicine, Airlangga University, Dr. Soetomo Hospital. Jalan Prof dr Moestopo 6-8, Surabaya 60286, Indonesia. Email: patriciasprm@yahoo.com

\section{INTRODUCTION}

The aging process of body's aging system in elderly would result in the loss of important functions in their ability to live independently and usually also accompanied by loss of work, spouse, friends and so on (Hening 1993, Granger et al 1996). Obesity, which is now classified as a disease, causes not only cosmetic complications but also more involves morbidity, such as heart, lung, diabetes and neuromusculoskeletal disorders that are related to functional, psychosocial and healthcare (Jensen \& Rogers 1998, McIntyre 1998, Poston et al 1998). Since WHO has stated that the definition of 'healthy' means not only the absence of disease, but also physi-cal, mental and social well-being, health system then underwent a change in perspective. Currently, health program targets are aimed at achieving better life and to maintain functional ability and well-being (Johnston et al 1992, Testa \& Simonson 1996). The measurement method which assesses the patient's perspective on functional ability and well being or quality of life is commonly called health-related quality of life (HRQL), which is more focused on health-related components (Guyatt et al 1993, Ware 1997). The HRQL assessment of the elderly with obesity will provide information on how much the impact of obesity in elderly on each component of life quality, such as physical and mental functioning and the consequences of disability. The assessment also compares the condi-tion both with other diseases and with healthy individu-als.

\section{MATERIALS AND METHODS}

This study was a cross-sectional study on all elderly patients in Geriatric Outpatient Unit, Medical and Diabetic Rehabilitation, Dr. Soetomo Hospital, Sura-baya who arrived in September-December 1999. Samples were taken with stratified random sampling and they had to fulfill the inclusion criteria as follows: age $\geq 60$ 
years old, cooperative and willing to be interviewed, and could understand the questions given. The samples were excluded if they had comorbid disease whose diagnosis had not been established, and they were unable to stand upright during height meas-urements. Patients who had met the inclusion and exclusion criteria were interviewed by the researchers to complete SF36 life quality questionnaire in Indone-sian, and weight and height measurements were carried out.

The aspects/dimensions measured in Indonesian SF-36 were physical functioning (PF), limitations of work/ other activities due to physical problems (RP), bodily pain (BP), social activities (SF), mental health (MH), limitations of work/other activities due to emotional problems (RE), vitality (fatigue/excitement) (VT), and general health $(\mathrm{GH})$ perception. Patients were grouped into two groups according to the definition of Management Consensus of Diabetes Mellitus in Indo-nesia PERKENI 1998 in which those who belong to obese group are women with BMI $>23.5 \mathrm{~kg} / \mathrm{m} 2$, and men with BMI $>25 \mathrm{~kg} / \mathrm{m} 2$, and non-obese group are women with BMI $\leq 23.5 \mathrm{~kg} / \mathrm{m} 2$ and men with $\mathrm{BMI} \leq 25 \mathrm{~kg} / \mathrm{m} 2$. BMI was calculated by the formula of bodyweight in kilograms divided by height in meters squared.

\section{Statistical analysis}

The sample distribution test was performed on all life quality component scores of SF-36. In addition, the scores of physical components of life quality, including the scores of PF, SF, BP, RP and GH, and the scores of mental components, including the scores of VT, RE and $\mathrm{MH}$, were also calculated. The difference between obese and non-obese groups was calculated by t-test. The estimation of controlled variable effect on the physical and mental components of MOS SF-36 was analyzed using multiple linear regression test.

\section{RESULTS}

The study sample was 105 patients, aged between $60-75$ years old with an average of 68.21 years old (SD 4.43 years), consisting of 62 male and 43 female. The characteristics of sociodemography and co-morbid di-sease of all separate samples in obese and non-obese groups are shown in Table 1 and co-morbid disease in Table 2. The average BMI of obese group was $27.16 \mathrm{~kg} / \mathrm{m} 2$ and the non-obese group was $21.23 \mathrm{~kg} / \mathrm{m} 2$.

Table 1. Socio-demographic characteristics of obese and non-obese groups

\begin{tabular}{lccc}
\hline & All samples (\%) & Obese group (\%) & Non-obese group (\%) \\
\hline Number of Sample & $105(100)$ & $49(46.7)$ & $56(53.3)$ \\
Gender & & & \\
$\quad$ Male & $62(59.1)$ & $24(49)$ & $38(67.9)$ \\
$\quad$ Female & $43(40.9)$ & $25(51)$ & $18(32.1)$ \\
Marital status & & & \\
$\quad$ Married, relatives (-) & $22(20.9)$ & $12(24.5)$ & $10(17.9)$ \\
Married, relatives (+) & $53(50.5)$ & $22(44.9)$ & $31(55.4)$ \\
Single, relatives (-) & $5(4.8)$ & $4(8.2)$ & $1(1.8)$ \\
$\quad$ Single, relatives (+) & $25(23.8)$ & $11(22.4)$ & $14(25)$ \\
Education & $20(19)$ & $8(16.3)$ & $12(21.4)$ \\
$\quad$ Elementary school & $32(30.5)$ & $14(28.4)$ & $18(32.4)$ \\
Junior high school & $32(30.5)$ & $15(30.6)$ & $17(30.4)$ \\
Senior high school & $21(20)$ & $12(24.5)$ & $9(16.1)$ \\
Diploma/bachelor degree & & & \\
Activities & $31(20)$ & $9(18.4)$ & $12(21.4)$ \\
$\quad$ With income & $84(80)$ & $40(81.6)$ & $44(78.6)$ \\
$\quad$ Without income & &
\end{tabular}

Table 2. Co-morbid disease in obese and non-obese groups

\begin{tabular}{lcc}
\hline \multicolumn{1}{c}{ Co-morbid diseases } & Obese group (\%) & Non-obese group (\%) \\
\hline Cardiac & $16(32.7)$ & $17(30.4)$ \\
Lungs & $7(32.7)$ & $5(8.9)$ \\
Knee pain & $26(54.2)$ & $21(37.5)$ \\
Lower back pain & $16(32.7)$ & $14(25)$ \\
Diabetes Mellitus & $20(40.8)$ & $20(35.7)$ \\
Hypertension & $39(79.6)$ & $35(62.5)$ \\
Dyslipidemia & $19(38.8)$ & $20(35.7)$ \\
\hline
\end{tabular}


After combining the eight aspect scores of SF-36 life quality, physical component scores of SF-36 (PCS) from PF, SF, RP, BP, GH and SF-36 mental component scores (MCS/ the scores of VT, MH, RE) showed normal distribution. The t-test score of physical components (PCS) and mental component (MCS) quality of life between obese and non-obese groups showed no significant difference in the averages of MCS and PCS scores between obese and non-obese groups ( $\mathrm{p}=0.45$ for MCS and $\mathrm{p}=0.97$ for PCS) (Table 3), although the obese PCS and MCS scores were higher than non-obese group's. In this case, socio-demographic factors and comorbidity diseases affecting the life quality were ignored.

Table 3. T-test of obese and non-obese groups

\begin{tabular}{lccc}
\hline Variables & $\begin{array}{c}\text { Obese group } \\
\text { mean (SD) }\end{array}$ & $\begin{array}{c}\text { Non-obese } \\
\text { group } \\
\text { mean (SD) }\end{array}$ & p value \\
\hline PCS & $\begin{array}{c}40.0977 \\
(6.152)\end{array}$ & $\begin{array}{c}40.05559 \\
(7.132)\end{array}$ & 0.974 \\
MCS & $\begin{array}{c}39.8543 \\
(7.934)\end{array}$ & $38.7702(6.816)$ & 0.453 \\
\hline
\end{tabular}

After these variables (age, sex, activity, education, marital status, shelter and co-morbid disease) were controlled through multiple linear regression test, we found significant differences in MCS score between the two groups $(\mathrm{p}=0.04)$, but the difference in PCS score was not significant $(\mathrm{p}=0.16)$ (Table 4).

Table 4. Multiple linear regression test of physical (PCS) and mental (MCS) components

\begin{tabular}{lcccc}
\hline \multicolumn{1}{c}{ Variables } & $\mathrm{B}$ & Significance & $\mathrm{B}$ & Significance \\
\hline Obesity & 2.03 & 0.16 & 3.35 & 4.04 \\
Diabetes & -2.16 & 0.33 & - & 0.21 \\
& & & 3.09 & \\
Diabetes & 0.25 & 0.08 & 0.26 & 0.11 \\
Mellitus & & & & \\
Hypertension & -2.79 & 0.08 & - & 0.33 \\
Cardiac & & & 1.71 & \\
Knee pain & -2.63 & 0.09 & - & 0.02 \\
& -2.07 & 0.15 & - & \\
LBP & & & 2.08 & 0.20 \\
& -1.81 & 0.24 & - & \\
Dyslipidemia & & & 1.50 & 0.38 \\
& -0.81 & 0.60 & - & 0.41 \\
Lungs & & & 1.41 & \\
& -3.68 & 0.88 & - & 0.05 \\
Gender & 0.85 & 0.66 & 0.57 & 0.78 \\
Age & 0.111 & 0.52 & 0.13 & 0.51 \\
Activities & 1.17 & 0.53 & 1.73 & 0.41 \\
Education & 1.3 & 0.54 & 0.72 & 0.76 \\
Status & 1.86 & 0.66 & 4.86 & 0.31 \\
\hline Significant if & & & & \\
& & & &
\end{tabular}

From the socio-demographic variables and other chronic diseases that we predicted to affect the quality of life of the elderly, the results showed that the presence/absence of heart disease had the greatest effect $(\mathrm{p}=0.02)$, followed by lung disease $(p=0.05)$. For mental and physical component of life quality were affected especially by heart disease and lung disease, but not significant $(\mathrm{p}=0.9)$

\section{DISCUSSION}

The results of this study indicated the life quality of obese group did not differ significantly with non-obese group although the quality of obese elderly life was slightly better than the non-obese group in mental and physical aspects. The differences between this study and the previous ones are that this study had difference in BMI of the subjects from the previous studies, difference in understanding of obesity, socio-cultural influences on life quality, as well as weaknesses and limitations of the study.

\section{Differences in BMI of study subjects with previous studies}

In Fontaine et al's (1996) study, the mean BMI on analyzed subjects was $38.1 \mathrm{~kg} / \mathrm{m} 2, \mathrm{SD} 8.4 \mathrm{~kg} / \mathrm{m} 2$, in which, according to Tjokroprawiro's (2000) the criteria belonged into severe obesity with severe morbidity risk; whereas in this study, the mean BMI of the obese group was lower at $27.16 \mathrm{~kg} / \mathrm{cm} 2$ and only one person with the highest BMI of $35.8 \mathrm{~kg} / \mathrm{m} 2$ (Table 3). This mean BMI values were classified as mild obesity with small risk of morbidity and also did not affect physical activity as the results of this study. In previous studies, the decline in physical component score (SF) and bodily pain (BP) was the factor that reduced life quality, even Lean et al (1999) only analyzed the physical functioning (PF) aspect as a result of obesity.

\section{Differences in understanding of obesity}

A different understanding of obesity also seemed to underlie the results of this study. For developed countries, obesity is clearly recognized by all medical personnel and society as a chronic disease that is also dangerous (Lean 1996), but in a developing country like Malaysia, $15 \%$ of subjects are unaware that obesity is bad for health (Jackson et al 1996). 88\% persons did not know that obesity was caused by food and lack of exercise, and $8 \%$ said that it was because persons lived happily. In addition, 51\% did not know that eating fatty and sweet would cause obesity. In the aspect of appearance, $15 \%$ of men said that obese was normal even more handsome, and $23 \%$ of women thought that 
obese was beautiful, although this study found a significant correlation between BMI and diabetes mellitus and hypertension. The Samoan population of the Pacific islands, too, had no negative view of obesity although having the opinion that thin body was ideal (Brewis et al 1998).

In Indonesia, it seems that overweight is a symbol of rich persons and success, although there has been no study of this. In Java, society is basically divided into two classes: the elite/priyayi/nobility class with elite culture and low-class that have mass culture. Nowadays, due to cultural democratization, society may easily move their class to exchange symbols and symbolic behavior (Kodiran 1985, Kuntowijoyo 1987). The rich and successful persons also need a symbol to be recognized for their higher status in a luxurious way of life and by purchasing the upper-class symbol (Onghokham 1997). The consumption of the society is not based on use value, but something that is considered as a symbol, because the image and reputation are considered as important things. Persons are willing to pay dearly for the benefit of the image, by, for example, buying certain goods, certain clothes, certain styles and expensive foods (Redana 1997). Changes in the type of food and where to buy foods that tend to be high in calories and sedentary lifestyle are symbol of all-fancy life, including the consequences of those lifestyle, which is the occurrence of obesity.

This also happens to elderly in Zimbabwe, as reported by Allain et al (1997). The frequency of high-calorie consumption (meat, milk, bread and fried food) is higher in populations with higher incomes and education. The elderly in urban Zimbabwe have higher anthropometric (BMI, WHR and skinfold) sizes than seniors in rural areas primarily because of more meat and fried foods. In rural areas, the more affluent population of the region has higher BMI as well.

\section{Socio-cultural influence on life quality}

Life quality, in addition to being influenced by health status, is also strongly influenced by the experience, beliefs, expectations and perceptions of a person (Testa \& Simonson 1996). Public perceptions of health/illness, in addition to being influenced by past experiences, are also strongly influenced by their socio-cultural factor (Scambler 1991, Sarwono 1993). Besides, illness behavior among different nations is in accordance with the socio-culture. In this study, subjects consisted primarily of Javanese tribe, who view human life as always adhering to orderly and hierarchical universe, which does not divide natural with supernatural, so that humans should thoroughly organize their society in harmony with universal order and also keep community in balance. The Javanese view of life emphasizes inner tranquility, harmony and equilibrium, attitudes toward all occurrences and placing oneself under society and the society under the universe (Mulder 1984, Koentjaraningrat 1987).

The life of community has been mapped in the rules of manners, traditional and moral norms that emphasize the attitude of accepting, not demanding, patient, and wary. Javanese cannot be separated from their society, removed from their group (silenced), or live in remote place because it may cause serious psychological reactions. They feel comfortable and protected in their group and are willing to have their actions, minds and heart set by their group, so that their psychological security can be regarded as originating from human environment; their identity and personality can be regarded as solely determined by community. Thus, Javanese rarely have realistic, principal decision derived from objective reason and self-belief (Mulder 1984).

Similarly, in answering the questionnaire SF-36, the respondents tended to give positive answer because of the attitude of accepting and not demanding on everything as it should be done. Javanese are also not required to have individual independence in group, thus things that interfere with independence is not considered to reduce quality of life.

In contrast, American has different values, which favors individual freedom. Individuals are the center of strength and value, and each individual has the right of freedom of thought and act in accordance with the wishes of the individual, and each individual must have equal opportunity to determine his/her life according to his/her ability. The attention to group is only as a means to achieve self-maturing goals and to improve the dignity and self-worth (Gabriel 1991).

\section{Weaknesses and limitations of the study}

The weakness and limitation of this study was that this study used SF-36, which is from USA, as a quality of life tool for Indonesians. The points in SF-36 that are adopted directly as life quality measurements seem to need to be modified/adjusted in relation to very different psycho-socio-cultural influences, although the aspects measured in them may be without change. Thus, this research was conducted only at Dr. Soetomo Hospital, so that it was not fully able to accurately describe the situation in society. In addition, this study did not meet the minimum number of samples, thus this study had the results which did not meet the requirements so it was not fully accountable. The results also showed that heart and lung disease affected the life quality of elderly significantly, as has been previously believed. In 
general, life quality measuring instrument used was also SF-36. Even in cardiovascular disease management efforts, SF-36 is not only used to measure life quality, but also as a measure of the success of an intervention (Lavie \& Milani 1995, Brown et al 1999). Normal SF36 scores for persons with hypertension, congestive heart failure, angina, and myocardial infarction have also been developed (Ware 1997).

In their study, Mahler and Mackowiack (1995) specified SF-36 as a valid instrument for COPD patients and stated that the severity of dyspnea was a predictor of seven SF-36 components. FEV1 was also a significant predictor of PF and RF components of SF-36. Mahler and Mackowiack also recommended to use valid measurement instruments and symptom measurement instruments to determine the quality of life of lung sufferers.

In social aspect, it is known that impairment of the elderly is associated with fewer contacts with friends and family, less feeling of having and real feelings of help. This low social support is an important factor in the decline in life quality and increased symptoms of depression in elderly (Newsom \& Schulz 1996).

However, in this study, the influence of social support, such as the presence or absence of families living together, the presence/absence of income, was insignificant towards the quality of life. This is in accordance with the study of Rudkin (1994) in Java which stated that for elderly, physical and residential dependence were not negative situation, except for the economic dependence which was burdensome. Communities in most agrarian countries pay tribute and high status to the elderly. This is in contrast to industrial societies, who often regard the elderly as a burden in society (Scambler 1991).

\section{CONCLUSION}

The study at outpatient clinic of Geriatrics, Diabetes and Medical Rehabilitation, Dr. Soetomo Hospital, Surabaya, showed that life quality of elderly with obesity was not worse than non-obese elderly. This was not in accordance with the hypothesis of this study. Some issues that underlied the mismatch between the results of the study and the hypothesis were the differences of study subjects with those in the previous studies. The average subjects of this study are those included in mild-obesity (according to NIH Classification was still overweight), difference in understanding obesity, and difference in socio-cultural influences quality of life.

\section{REFERENCES}

Allain TJ et al (1997). Diet and nutritional status I elderly Zimbabweans. Age Ageing 26, 463-70

Brewis AA et al (1998). Perceptions of body size in Pacific Islanders. Int J Obes Relat Metab Disord. 22, 185-9

Brown N et.al (1999). Quality of life four years after acute myocard infarction: SF-36 scores compared with a normal population. Heart $81,352-8$

Fontaine KR, Cheskin LJ, Barofky I (1996). Healthrelated quality of life in obese persons seeking treatment. J of Fam Pract 43, 265-70

Gabriel RH (1991). Nilai-Nilai Amerika. Pelestraian dan Perubahan. Yogyakarta: Gadjah Mada University Press

Granger RV et.al (1996). Quality and outcome measures for rehabilitation. in: Braddom RL (ed). physical medicine and rehabilitataion, Philadelphia, WB Sauders Company, p 239-54

Guyatt GH, Feeny DH, Patrick DL (1993). Measuring health-related quality of life. Ann Int Medd 118, 622-9

Hening LP (1993). Manula dan upaya rehabilitasi preventif. Media IDI 18, 27-31

Jackson A et al (1996). Obesity in primary care patients in Kelantan, Malysia: Prevalence, and patients' knowledge and attitudes. Southeast Asian J Trop Med Public Health 27, 776-9

Jensen CL, Rogers L (1998). Obesity in older persons. J Am Diet Assoc 98, 1308-11

Johnston MV, Keith RA, Hinderer SR (1992). Measurement standart for interdisiplinary medical rehabilitation. Arch Phys Med Rehabil 73, S3-S4

Lavie CJ, Milani RV (1995). Effects of cardiac rehabilitation programs on exercise capasity, coronary risk factors, behavioural characteristics and quality of life in a large elderly cohort. Am. J Cardiology 76, 177-9

Lean MEJ, Han TS, Seidell JC (1999). Impairment of health and quality of life using new US federal guidelines for the identification of obesity, Arch. Int. Med 159, 837-43

Lean MEJ (1996). Obesity. A Clinical Issue, London, Science Press

Mahler DA, Mackowiak JI (1995). Evaluation of the short form 36-item questionare to measure healthrelated qualaity of life in patients with COPD. Chest 107, 1585-89

McIntyre M, 1998. Burden of illness review of obesity. Are the true costs realised? JR Soc. Health 118, 76-84

Mulder N (1984). Kepribadian Jawa dan pembangunan nasional, Yogyakarta, Gadjah Mada University Press, p 12-90

Newsom JT, Schulz R (1996). Social support as a mediator in the relation between functionaal status aand 
quality oof life in older adults. Psychol Aging 11, 3444

Onghokham (1997). Show kemewahan, suatu simbol sukses. In: Ibrahim IS (ed). Ectasy gaya hidup. Kebudayaan pop dalam masyarakat komoditas Indonesia, Bandung, Penerbit Mizan, p 175-9

Perkumpulan Endokrinologi Indonesia (PERKENI) (1998). Konsensus pengelolaan diabetes melitus di indonesia. Jakarta: Perkumpulaan Endokrinologi Indonesia (PERKENI)

Poston WS et al (1998). Challenges in obesity management. South Med J 91, 710-20

Redana B. 1997. Ongkos Sosial Gaya Hidup Mutakhir. In: Ibrahim IS (ed). Ectasy gaya hidup. Kebudayaan pop dalam masyarakat komoditas Indonesia, Bandung, Penerbit Mizan, p 180-90

Rudkin L (1994). Dependency status and happiness with old age on Java. Gerontologist 34, 217-23
Scambler G (1991). Health and ilness behaviour. In: Scambler G (ed). Sociology as applied to medicine. 3rd ed, London, Baillire-Tindall, p 33-46

Testa MA, Simonson DC (1996). Assessment of quality of life outcomes. NEJM 334, 835-40

Tjokroprawiro A (2000). Obesity, a chronic disease and predictor. In: Symposium: Is obesity a disease? Surabaya, 15 April 2000

Ware JE (1997). SF-36 health survey. Manual and intepretation guide, Boston, New England Medical Center

Sarwono (1993). Teori-teori psikologi sosial, Jakarta, PT Raja Grafin Persada

Kodiran (1985). Kebudayaan Jawa. Koentjaraningrat (redaksi). Manusia dan Kebudayaan di Indonesia. Jakarta, Penerbit Djambaran

Koentjaraningrat (1987). Sejarah teori antropologi, Jakarta, UI-Press

Kuntowijoyo (1987). Budaya dan masyarakat, Yogyakarta, Penerbit Tiara Wacana. 